\title{
Cortisol Inhibition of $17 \beta$-Estradiol Secretion by Rainbow Trout Ovarian Follicles Involves Modulation of Star and P450scc Gene Expression
}

\author{
S. Barkataki', N. Aluru', M. Li', L. Lin', H. Christie', M.M. Vijayan ${ }^{3}$ and J.F. Leatherland ${ }^{1 *}$
}

${ }^{1}$ Department of Biomedical Sciences, University of Guelph, Guelph, ON N1G 2W1, Canada

${ }^{2}$ Biology Department, Woods Hole Oceanographic Institution, Woods Hole, MA 02543, USA

${ }^{3}$ Department of Biology, University of Waterloo, Waterloo, ON N2L 3G1, Canada

\begin{abstract}
Maternal stress associated with elevated maternal cortisol levels has well-demonstrated adverse affects on reproduction in vertebrates, including impaired ovarian steroidogenesis. Currently, the potential sites of action of cortisol on ovarian function are not known. Studies were carried out to examine the mechanism(s) by which cortisol suppresses steroidogenesis by mid-vitellogenic stage rainbow trout (Oncorhynchus mykiss) ovarian follicles. $17 \beta$-Estradiol and testosterone synthesis, and the expression of key steroidogenesis-related genes (using real time RT-PCR) were measured. Follicles were also incubated in the presence of several tritium-labelled steroids $\left(\left[{ }^{3} \mathrm{H}\right] 17 \mathrm{\alpha}\right.$-hydroxyprogesterone, $\left[{ }^{3} \mathrm{H}\right]$ testosterone, $\left[{ }^{3} \mathrm{H}\right]$ androstenedione $)$, and the tritium-labeled steroid products were separated by reverse-phase HPLC to look for possible affects of cortisol on specific steroidogenic enzyme function. Cortisol inhibited $17 \beta$-estradiol and testosterone synthesis, but had no affect on the formation of tritium-labelled estrogens from any of the tritium-labeled substrates, suggesting that the suppressive action of the glucocorticoid did not operate by inhibiting estrogen synthesis from androgens. Conversely, in the presence of cortisol in the medium, the relative expression of genes encoding for steroidogenic acute regulatory (StAR) protein and P450 side chain cleavage (P450scc) enzyme was suppressed, suggesting that the cortisol inhibition of steroidogenesis is prior to the synthesis of progestogens, possibly inhibiting either the expression and/or turnover of the genes encoding for StAR and P450scc proteins. The study shows that maternal stress during the critical phase of follicle vitellogenesis will have deleterious effects on oocyte development and growth.
\end{abstract}

Keywords: Glucocorticoid; Ovarian steroidogenesis; Salmonid fish; StAR gene expression; P450scc gene expression; Thecal cells; Granulosal cells

Abbreviations: $\mathrm{A}_{4}$ : androstenedione; cAMP: cyclic adenosine monophospate; $\mathrm{E}_{2}$ : 17ß-estradiol; GR: glucocorticoid receptor; HPLC: high performance liquid chromatography; HPO: hypothalamus-pituitary glandovary; 17OHP: 17 $\alpha$-hydroxyprogesterone; P450arom: P450 aromatase; P450scc: P450 side chain cleavage; PSM: polar steroid metabolites; qPCR: real time (or semi-quantitative) RT-PCR; RT-PCR: reverse transcriptase polymerase chain reaction; StAR: steroidogenic acute regulatory; T: testosterone

\section{Introduction}

The general consensus in the applied research community is that maternal stress adversely affects reproduction in vertebrates [1-4]. However, despite extensive research over the last several decades, the mechanisms of action of stressors and "stress hormones" such as cortisol on reproductive functions have not been well-defined. This is probably because there is no single site of action of glucocorticoids on reproductive function. Rather, there are multiple sites of interaction of stress-related hormones on the maternal hypothalamus-pituitary gland-ovary (HPO) axis, as well as extensive metabolic outcomes, in addition to direct action on gonad function itself that have significant consequences for the development and maturation of gametes.

In mammals, high levels of free glucocorticoids are present in the ovarian follicle antral fluid and glucocorticoid receptors (GRs) are present in ovarian tissues [5-12], suggesting an essential role for the glucocorticoid in oocyte development and maturation, possibly by modulating the meiotic competence of the oocyte [7]. Elevated ovarian glucocorticoids were found to have adverse affects on the maturation of oocytes and increased anovulation [13-17], but it is not clear whether these responses can be attributed to a direct action of the glucocorticoids on ovarian steroidogenesis.

Similarly, in teleost fishes, although stressor-related impairments of ovarian maturation in vivo are well established [1,2,18-20], most of these can be attributed to stressor-related decreases in food intake, glucocorticoid-enhanced metabolism of nutrient reserves, or glucocorticoid-related depression of immune system function, the so-called allostatic load factors [21], the net affect of which is the redirection of resources away from ovarian follicle development and maturation $[1,2,18,20]$. Yet other responses to elevated maternal cortisol in fish appear to be actions on at different levels on the HPO axis, or by inhibiting hepatic vitellogenin synthesis in oviparous species, which impairs oocyte growth [1].

It is known is that that cortisol of maternal origin is transferred to the oocytes of teleost fishes during gonadal maturation, and increases in maternal plasma cortisol levels are reflected in increases in oocyte cortisol content [1]. In addition, the genes encoding for the glucocorticoid receptor (GR) proteins, GR1 and GR2 are expressed in fish ovarian follicles, and GR protein is present in the thecal and granulosal cells of preovulatory rainbow trout (Oncorhynchus mykiss) ovarian follicles [22-24]. These observations suggest a direct involvement of glucocorticoids in normal ovarian steroidogenesis,

*Corresponding author: John F. Leatherland, University of Guelph, Guelph, ON N1G 2W1, Canada, Tel: +01-519-824- 4120, Fax: +01-519-767-1460; E-mail: jleather@ovc.uoguelph.ca

Received June 12, 2011; Accepted October 18, 2011; Published November 04 2011

Citation: Barkataki S, Aluru N, Li M, Lin L, Christie H, et al. (2011) Cortiso Inhibition of $17 \beta$-Estradiol Secretion by Rainbow Trout Ovarian Follicles Involves Modulation of Star and P450scc Gene Expression. J Aquac Res Development S2:001. doi:10.4172/2155-9546.S2-001

Copyright: (c) 2011 Barkataki S, et al. This is an open-access article distributed under the terms of the Creative Commons Attribution License, which permits unrestricted use, distribution, and reproduction in any medium, provided the original author and source are credited. 
and as a consequence, there is the potential for modulation of ovarian steroidogenesis by elevated maternal plasma cortisol concentrations, and thus adverse actions of the hormones on the development of oocytes. Therefore, there is a need to consider the possible influence of aquaculture husbandry practices, some of which are known do evoke a stress-response in brood stock, on ovarian function and oocyte quality. Commonly, fertilization rates are used in aquaculture practice as the indicator of oocyte quality. However, recent studies have shown that relatively small changes in oocyte content prior to the fertilization of rainbow trout oocytes, although having no affect on fertilization capacity of oocytes, bring about epigenetic changes in the oocyte (maternal) genome that have long-lasting affects on the phenotype of the progeny $[24,25]$. Thus, measures other than fertilization rates should be included in that assessment of the impact of aquaculture practices.

In order to examine possible direct actions of cortisol on ovarian steroidogenesis, and by-pass any possible involvement of the glucocorticoid in HPO axis activity, ovarian follicles were incubated, in vitro, in the presence of cortisol. Previous studies have shown that when ovarian follicles at the mid-vitellogenic stage of maturation, when the estrogenic and androgenic steroidogenic capacity of the follicle is at a maximum, are incubated in medium containing cortisol, the synthesis of $17 \beta$-estradiol $\left(\mathrm{E}_{2}\right)$ and testosterone $(\mathrm{T})$ by the follicles is significantly suppressed [26]. However, the mechanisms and sites of action of the glucocorticoid on the steroidogenic cascade by which steroidogenesis is inhibited are currently not known. The present series of studies attempts to determine the points in these steroidogenic pathways that are impacted by the presence of cortisol in the medium; the effects of the glucocorticoid was examined in follicles that were not receiving $\mathrm{LH}$ receptor-stimulated intracellular increases in cAMP (basal steroidogenesis), and follicles that were being stimulated to secrete intracellular cAMP by the inclusion of the adenylate cyclase activator, Forskolin, in the incubation medium (cAMP-stimulated steroidogenesis). This approach was chosen to evaluate whether cortisol suppresses cAMP-stimulated as well as basal steroidogenesis. A series of studies were undertaken to specifically examine the possible sites of inhibitory action of cortisol on four different levels of steroidogenesis, as shown in Figure 1. These were the rate-limiting step in gonadal steroidogenesis is the cAMP-regulated transfer of cholesterol (by the activation of the cholesterol transporter, steroidogenic acute regulatory (StAR) protein) from the cytosol of steroidogenic cells into the inner chamber of the mitochondria, or the expression of the gene encoding for StAR protein [26-30] (A), the conversion of cholesterol to pregnenolone (P5) in the inner mitochondrial chamber by the action of the enzyme, cytochrome P450 side chain cleavage (P450scc) (B), the biotransformation of progestogens to androgenic steroids by enzymes associated with the smooth endoplasmic reticulum of the thecal cells (C), and the aromatization of the androgenic steroids to estrogens by specific isoforms of cytochrome P450 aromatase (P450arom) within the granulosal cells (D).

\section{Materials and Methods}

\section{Chemicals}

Testosterone $(\mathrm{T})$ and $17 \beta$-estradiol $\left(\mathrm{E}_{2}\right)$, bovine serum albumin, L-glutamine, $\beta$-D-glucose, bovine $\beta$-glucuronidase, Forskolin, and cortisol were purchased from Sigma (Sigma-Aldrich Canada Ltd, Oakville, ON, Canada). The tritium-labelled compounds were purchased as follows: $\left[1,2,6,7-{ }^{3} \mathrm{H}\right] 17 \alpha$-hydroxyprogesterone $\left(\left[{ }^{3} \mathrm{H}\right] 17 \mathrm{aOHP}_{4}\right)$ [specific activity $67.0 \mathrm{Ci} . \mathrm{mmol}$, Amersham Canada, Oakville, ON], $\left[1,2,6,7-{ }^{3} \mathrm{H}\right.$ ] T [specific activity 95.0 Ci.mmol, NEN

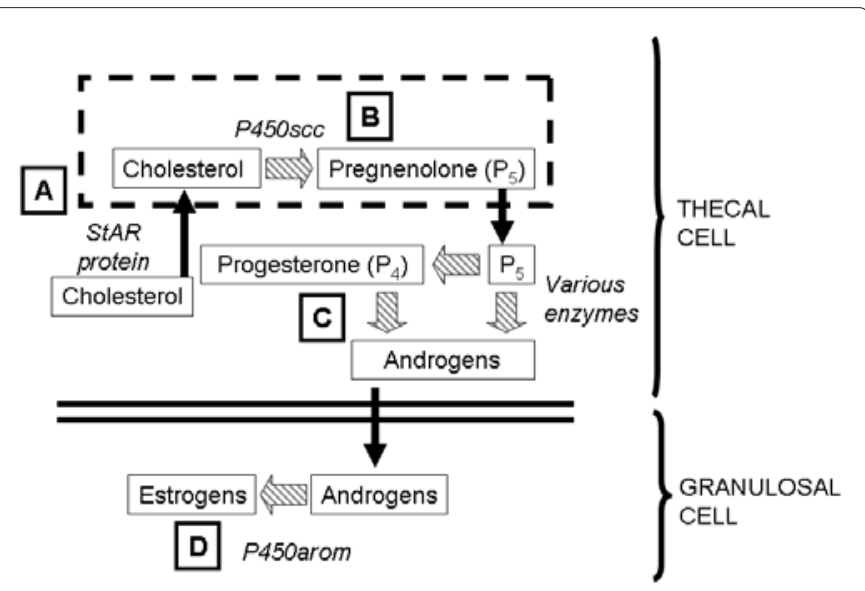

Figure 1: Schematic outline of the major components of ovarian steroidogenesis considered as possible sites of action of cortisol in the present study. The numbers in circles indicate the sites of specific investigation. 1. The transport of cholesterol from the cytoplasm of the thecal cells into the mitochondria (shown as box with dotted outline, by the involvement of the steroidogenic acute regulatory protein transporter. 2. The conversion within the mitochondria of cholesterol to pregnenolone $\left(P_{5}\right)$ by the enzyme P450 side change cleavage (P450scc). 3. The multi-enzyme systems associated with the smooth endoplasmic reticulum of the thecal cells that convert $P_{5}$ by several stages into androgenic steroid. 4 . The aromatization of androgenic steroids by the enzyme P450 aromatase (P450arom) to form estrogenic steroids, principally $17 \beta$-estradiol $\left(E_{2}\right)$ and estrone $\left(E_{1}\right)$.

Canada, Lachine, PQ], $\left[1 \beta, 2 \beta-{ }^{3} \mathrm{H}\right]$ androstenedione $\left(\left[{ }^{3} \mathrm{H}\right] \mathrm{A}_{4}\right)$ [specific activity 45.9 Ci.mmol, NEN Canada, Lachine, $\mathrm{PQ}]$ and $\left(\left[1,2,6,7-{ }^{3} \mathrm{H}\right] \mathrm{A}_{4}\right.$ [specific activity 101.0, Ci.mmol PerkinElmer, Shelton, CT]. Reagent grade solvents and glass-distilled HPLC grade acetonitrile were purchased from Caledon Laboratories, Ltd., Georgetown, ON.

\section{Source of tissue and identification of mid-vitellogenic ovaries}

The protocols for the use of all animals for this study were reviewed and approved by the University of Guelph Animal Care Committee. All of the ovarian samples for the study were collected from brood stock maintained at the Ontario Ministry of Agriculture and Food Alma Aquaculture Research Station (ARS), Alma, ON, Canada; a total of 40 rainbow trout were used in various parts of the study. Prior to sampling, the fish were held in constantly aerated and running artesian well water in outside holding aquaria, and fed daily to satiety with a commercial trout diet. Prior to the spawning period, all fish in the breeding stock were examined weekly by the ARS Staff to assess their reproductive state. Each fish was captured randomly from the aquarium and its abdomen was gently palpated to confirm that the fish had not ovulated, and killed by a blow to the head. The carcasses were then placed on ice and transported from the research station to the University of Guelph where the follicles were harvested for incubation.

The physiological parameters that were used to identify ovaries that were at a mid-vitellogenic stage were basal and Forskolin-stimulated (cAMP-stimulated) $\mathrm{E}_{2}$ and $\mathrm{T}$ synthesis by follicles in vitro. Only the ovarian follicles $(n=20)$ that demonstrated physiological characteristics indicative of mid-vitellogenic stage follicles (namely high basal $\mathrm{E}_{2}$ and $\mathrm{T}$ synthesis, and the capacity to respond further to cAMP-stimulation) [23], were included in the finding presented in this study.

\section{Tissue preparation and in vitro incubations of ovarian follicles}

Freshly-dissected ovarian tissue from each fish was placed in icecold Cortland's medium (supplemented with $0.1 \%$ glucose, $0.1 \%$ bovine 
Citation: Barkataki S, Aluru N, Li M, Lin L, Christie H, et al. (2011) Cortisol Inhibition of 17ß-Estradiol Secretion by Rainbow Trout Ovarian Follicles Involves Modulation of Star and P450scc Gene Expression. J Aquac Res Development S2:001. doi:10.4172/2155-9546.S2-001

serum albumin, and $0.1 \%$ streptomycin sulfate at $\mathrm{pH} 7.55$ ) and kept at a low temperature throughout the preparation of individual ovarian follicles for incubation, as described previously [31-33].

For the assessment of the maturational state of individual fish, follicles were separated from the ovaries of each animal and placed in 24-well cell culture plates (10 follicles per well, $1 \mathrm{ml}$ of supplemented Cortland's medium per well; the culture plates were placed on a bed of ice, until fresh medium (containing Forskolin, T, cortisol, or tritiumlabeled steroids, where appropriate) was added to the wells immediately prior to commencement of the incubation.

Groups of follicles from each fish were allocated to four treatment groups (12 replicates each). Two groups each were incubated either in the absence (basal steroidogenesis) or presence of $10 \mu \mathrm{M}$ of the adenylate cyclase stimulator, Forskolin (to simulate cAMP-stimulated steroidogenesis). One of the basal and one of the cAMP-stimulated treatment groups were incubated in the presence of cortisol (10 ng.ml-1). The four treatment groups were: Basal (control), Basal + cortisol, cAMP-stimulated, and cAMP-stimulated + cortisol. The concentration of cortisol chosen for the study was based on preliminary trials [23]. Additional incubations of the four treatment groups (12 replicates) were carried out in the presence of $\left[{ }^{3} \mathrm{H}\right] 17 \mathrm{aOHP},{ }_{4},\left[{ }^{3} \mathrm{H}\right] \mathrm{T}$, or $\left[{ }^{3} \mathrm{H}\right] \mathrm{A}_{4}(0.75 \mu \mathrm{Ci}$ per well $)$. Additional incubations of the Basal and Basal + cortisol treatment groups (12 replicates) were made in which $\mathrm{T}$ was added to the medium (10 or 100 ng. $\left.\mathrm{ml}^{-1}\right)$.

All incubations were carried out at $8-10^{\circ} \mathrm{C}$ for $18 \mathrm{~h}$; the medium was then harvested and stored at $-20 \mathrm{oC}$ until they were analyzed. Ovarian follicles from each treatment group were then placed in RNA later for $24 \mathrm{~h}$ at $8-10^{\circ} \mathrm{C}$, following which they were frozen and stored at $-20^{\circ} \mathrm{C}$ for later extraction of mRNA.

\section{Radioimmunoassays}

Radioimmunoassays (RIAs) were used to measure the concentrations of $\mathrm{E}_{2}$ and $\mathrm{T}$ in the medium as described previously $[32,33]$. To determine the specificity of the assays, free steroids that had been extracted from the medium were separated by HPLC; the fractions were then dried under nitrogen, reconstituted in phosphate-buffered saline and the steroid levels measured in the reconstituted fractions.

\section{Extraction and separation of tritium-labeled steroids from the incubation medium}

The medium of containing tritium-labeled steroids was subjected to solid phase extraction (SPE) using Sep-Pak $\mathrm{C}_{18}$ cartridges (Waters Corp, Milford, MA, USA) to extract the steroids as described previously [33]. In brief, the incubation medium (pooled from 3 incubation wells for each treatment group) was applied to a primed cartridge, and allowed to filter through the cartridge (the filtrate was collected). The unconjugated (free) steroid fraction was eluted by passing $5 \mathrm{ml}$ of diethyl ether through the cartridge, and the conjugated steroid fraction was then eluted by passing $5 \mathrm{ml}$ of methanol through the cartridge. Both diethyl ether and methanol fractions were dried under nitrogen at $<45^{\circ} \mathrm{C}$ and the sulfate and glucuronide conjugates were sequentially separated as free steroids following acid solvolysis (sulfate) and glucuronidase treatments (glucuronide), respectively [31-33]. To measure the recovery of tritium-labeled steroid at each separation step, a $100 \mu \mathrm{l}$ aliquot was taken from each fraction, mixed with $4 \mathrm{ml}$ of scintillation cocktail (Ecolite, MP Biochemicals, Solon, OH), and counted in a Searle Delta 300 counter.

The radiolabeled steroids (free and conjugated) in the extracts of the incubation medium were separated using reverse phase high performance liquid chromatography (HPLC). The HPLC system (Waters) was equipped with a Waters Model 2690 Alliance Separation Module and Waters 996 Photodiode Array Detector. Millenium 32 Software was used to create a binary gradient (Waters \#8) of acetonitrile:water, from 28:72 to 90:10, over $40 \mathrm{~min}$, on a Waters NovaPak $\mathrm{C}_{18}(150 \mathrm{~mm} \times 39 \mathrm{~mm}, 4 \mu \mathrm{m})$ column. The flow rate was 0.7 ml.min-1. The absorbance was monitored at 254 and $280 \mathrm{~nm}$. Fractions of the eluate were collected using a Waters fraction collector, and radioactivity levels in $0.5 \mathrm{~min}$ fractions of the eluate were measured as described above.

\section{RNA extraction}

A RNeasy ${ }^{\circ}$ Lipid Tissue Mini kit (Qiagen Sciences, Maryland, USA) was used to extract total RNA from ovarian follicles. The frozen follicles were quickly thawed in lysis buffer (3-4 follicles. $\left.\mathrm{ml}^{-1}\right)$, and then homogenized following the protocol described previously [34]. The total RNA was measured at $260 \mathrm{~nm}$ in a UV spectrophotometer, and calculated as total RNA content per follicle. Each assay of total follicle RNA was performed in triplicate. The integrity of the total RNA was examined using a $1.2 \%$ formaldehyde agarose RNA gel with ethidium bromide.

The total RNA for each sample $(1 \mu \mathrm{g})$ was reverse-transcribed to cDNA using the First Strand cDNA synthesis kit (MBI Fermantas, USA); the procedure utilized was that recommended by the supplier. Briefly, total RNA was heat denatured at $70^{\circ} \mathrm{C}$ and cooled on ice. The sample was used in a $20 \mu \mathrm{l}$ reverse transcriptase reaction using $0.5 \mu \mathrm{g}$ oligo $\mathrm{d}(\mathrm{T})$ primers and $1 \mathrm{mM}$ of dNTP, $20 \mathrm{U}$ ribonuclease inhibitors, and $40 \mathrm{U}$ of $\mathrm{M}-\mathrm{MuLV}$ reverse transcriptase. The reaction was incubated at $37^{\circ} \mathrm{C}$ for $1 \mathrm{~h}$ and stopped by heating at $70^{\circ} \mathrm{C}$ for $10 \mathrm{~min}$.

\section{Quantitative real time RT-PCR (qPCR) measurements}

Primer design and validation: The primers for StAR, P450scc, $\beta$-actin, and elongation factor- $1 \alpha$ (EF-1 $\alpha)$ were based on rainbow trout StAR (accession number NM_001124202), P450scc (S57305), $\beta$-actin (AJ438158), and EF-1 $\alpha$ (AF498320) cDNA sequences and used to amplify $\sim 101$ bp for StAR, 140 bp for P450scc, 105 bp for $\beta$-actin, and $\sim 125$ bp for EF-1 $\alpha$ products for use in qPCR. The amplifying temperature was $60^{\circ} \mathrm{C}$ for all the genes used in the qPCRs. The primer sequences are shown in Table 1 . Both $\beta$-actin and EF-1a reference genes were measured, but only $\beta$-actin was used for normalization of the other genes because it was more stable than EF-1 $\alpha$ across all the experimental treatments.

Standard curves: Plasmids with target sequence inserts were used to establish standard curves. Standard curves were generated using a serial dilution of the plasmids to attain varying copy numbers of insert

\begin{tabular}{|l|l|}
\hline Gene & Primers \\
\hline StAR & Forward 5'-TGGGGAAGGTGTTTAAGCTG-3' \\
\hline & Reverse 5'-AGGGTTCCAGTCTCCCATCT-3' \\
\hline P450ssc & Forward 5'-GCTTCATCCAGTTGCAGTCA-3' \\
\hline 3-Actin & Reverse 5'-CAGGTCTGGGGAACACATCT-3' \\
\hline & Forward 5'-TGTCCCTGTATGCCTCTGGT-3' \\
\hline EF-1a & Reverse 5'-AAGTCCAGACGGAGGATGG-3' \\
\hline & Forward 5'-CATTGACAAGAGAACCATTGA-3' \\
\hline & Reverse 5'-CCTTCAGCTTGTCCAGCAC-3' \\
\hline
\end{tabular}

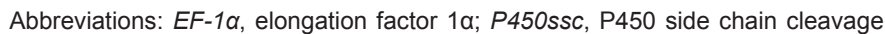
StAR, steroidogenic acute regulatory.

Table 1: Oligonucleotide primers used in the real time RT-PCR analysis. 
Citation: Barkataki S, Aluru N, Li M, Lin L, Christie H, et al. (2011) Cortisol Inhibition of 17ß-Estradiol Secretion by Rainbow Trout Ovarian Follicles Involves Modulation of Star and P450scc Gene Expression. J Aquac Res Development S2:001. doi:10.4172/2155-9546.S2-001

sequences (108 - 101 copies). Each standard reaction mix contained 1 $\mu \mathrm{l}$ of cDNA, $4 \mathrm{pM}$ of each primer and SYBR green super mix, $1 \mathrm{U} . \mathrm{ml}$ 1 of iTaq DNA polymerase, $40 \mathrm{mM}$ of Tris- $\mathrm{HCl}(\mathrm{pH} 8.4), 100 \mathrm{mM}$ of $\mathrm{KCl}, 6 \mathrm{mM}$ of $\mathrm{MgCl} 2,0.4 \mathrm{mM}$ of each dNTP component (dATP, dGTP, $\mathrm{dCTP}$ and dTTP) SYBR Green 1,20 $\mu \mathrm{M}$ of fluorescein and stabilizers in a total volume of $25 \mu$ l. Real time RT-PCR (qPCR) was performed using an iCycler $\mathrm{iQ}^{\mathrm{TM}}$ (BioRad) under the following conditions: 2 min at $94^{\circ} \mathrm{C}$ followed by 40 cycles of $15 \mathrm{~s}$ at $95^{\circ} \mathrm{C}$ and $30 \mathrm{~s}$ at respective annealing temperature. PCR products were subjected to melt curve analysis to confirm the presence of a single amplicon. Control reactions were conducted with no cDNA template and with RNA to determine the level of background or genomic contamination. Master mixes were prepared at every stage for triplicate reactions $(3 \times 25 \mu \mathrm{l})$ for each standard to minimize pipetting errors. Specific 96-well PCR plates were used according to the manufacturer's instructions (BioRad, Richmond, CA).

Quantification of samples: A diluted cDNA sample $(1 \mu \mathrm{l}$ of 1:1 diluted with DEPC-treated water) was used as a template for every $25 \mu \mathrm{l}$ reaction and each sample was set-up in triplicate for the qPCR. The reaction components were exactly the same as in the previous section and for every single test sample; a qPCR for both the target and the housekeeping genes was performed. The following PCR reaction conditions were: 1 cycle: $95^{\circ} \mathrm{C}(3 \mathrm{~min}) ; 40$ cycles: denature $95^{\circ} \mathrm{C}(30 \mathrm{~s})$, anneal $60^{\circ} \mathrm{C}(30 \mathrm{~s})$, followed by $4^{\circ} \mathrm{C}$ hold.

\section{Statistical analysis}

One-way analysis of variance was used to analyse the affects of cortisol on mid-vitellogenic follicles. Intra-animal data were normalized to the value of the control treatment group for each animal, so that the data from several animals could be pooled. The data were expressed as mean \pm SEM. The data were $\log 10$ transformed, wherever necessary, to obtain homogeneity of variance. Where $\mathrm{F}$ values indicated significant differences $(P<0.05)$, Dunn's method test was used to test the differences between means. A probability level of $\mathrm{P} \leq 0.05$ was considered to be significant. Comparisons of control and cortisoltreated groups incubated in the absence or presence of $\mathrm{T}$ were made using Student's t test.

\section{Results}

The effects of cortisol on in vitro basal and cAMP-stimulated $17 \beta$-estradiol $\left(\mathrm{E}_{2}\right)$ and testosterone $(\mathrm{T})$ secretion

Both $\mathrm{E}_{2}$ and $\mathrm{T}$ secretion by ovarian follicles incubated in vitro in the presence of cortisol was significantly lower $(\mathrm{P}<0.01$ and $\mathrm{P}<0.05$ for $\mathrm{E}_{2}$ and $\mathrm{T}$, respectively) relative to the controls; this was the case for both basal and cAMP-stimulated follicles (Figure 2). The mean basal and cAMP-stimulated $\mathrm{E}_{2}$ productions were $0.78 \pm 0.06$ and $1.05 \pm 0.05$ pg.follicle ${ }^{-1}$, respectively; these differed significantly $(\mathrm{P}<0.01)$ from one another. The mean basal and cAMP-stimulated $\mathrm{T}$ productions were $0.46 \pm 0.05$ and $5.29 \pm 1.68$ pg.follicle ${ }^{-1}$, respectively; these means differed significantly $(\mathrm{P}<0.01)$ from one another.

To determine the specificity of the $\mathrm{E}_{2}$ and $\mathrm{T}$ radioimmunoassays, incubation medium (pooled from several preparations) was subjected to solid phase extraction (SPE), followed by separation of the steroids by reverse phase HPLC, and measurement of $\mathrm{E}_{2}$ and $\mathrm{T}$ concentrations in the HPLC fractions. $\mathrm{E}_{2}$ and $\mathrm{T}$ were only detectable by the assays in those fractions that had retention times the same as authentic reference standards for the two steroids (data not shown).

The effect of cortisol on the in vitro basal secretion of $17 \beta$-estradiol
$\left(\mathrm{E}_{2}\right)$ by ovarian follicles incubated in the presence of testosterone $(\mathrm{T})$

Testosterone was added to the medium to determine if cortisol acted at the level of the aromatization of $\mathrm{T}$ to $\mathrm{E}_{2}$ by granulosal cells. With $\mathrm{T}$ in the incubation medium there was a significant increase in basal $\mathrm{E}_{2}$ production $(\mathrm{P}<0.05$ and $\mathrm{P}<0.01$ for $\mathrm{T}$ treatment groups at 10 and 100 ng.ml-1, respectively) (Table 2). There were no significant differences in any of the cortisol-treated groups with $\mathrm{T}$ incorporated in the medium and their comparable control treatment groups (Table 2).

The effect of cortisol on the relative abundance of StAR and P450scc mRNA transcripts

The presence of cortisol in the medium significantly reduced the relative abundance of StAR and P450scc mRNA transcripts in the basal treatment groups $(\mathrm{P}<0.01)$ (Table 3$)$. The relative abundance of StAR mRNA was significantly higher $(\mathrm{P}<0.01)$ in the cAMP-stimulated treatment group than in the basal control group. However, in the cAMP treatment group incubated in the presence of cortisol, both StAR and P450scc mRNA relative abundance was significantly $(\mathrm{P}<0.01)$ higher than in all other treatment groups (Table 3).

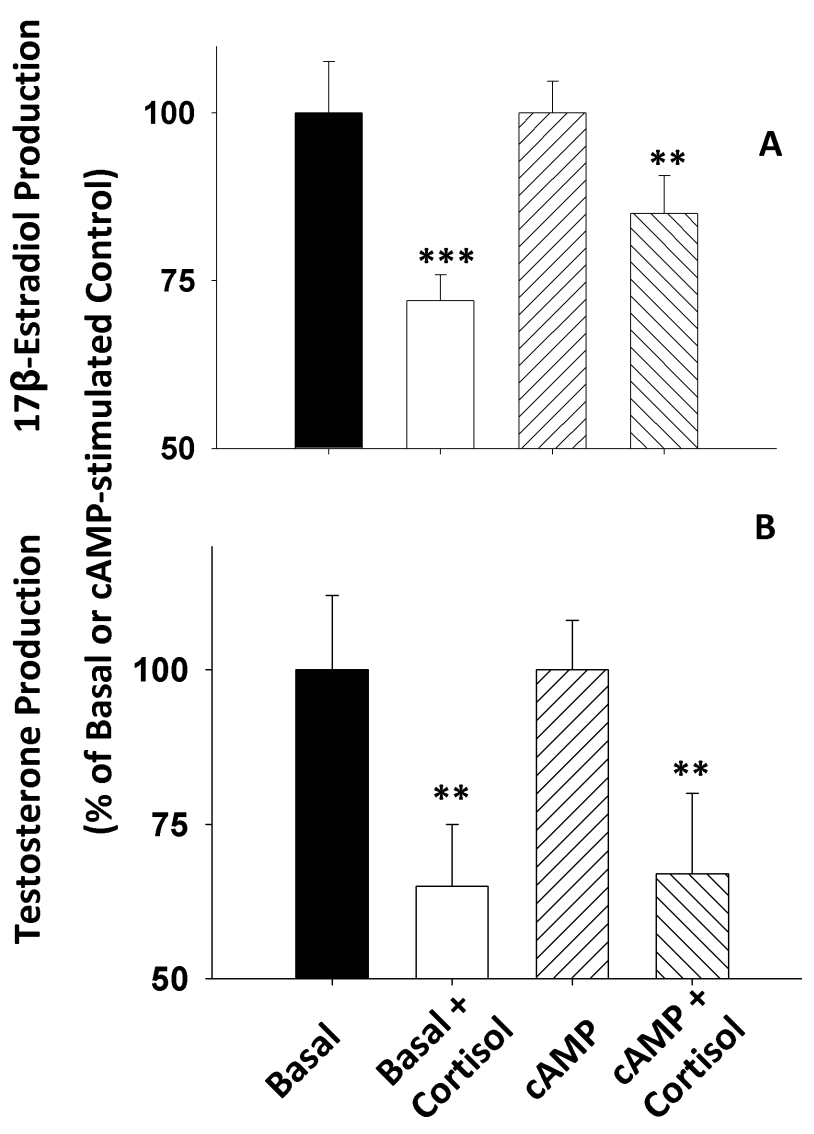

Figure 2: Affect of cortisol on (A) 17 -estradiol $\left(E_{2}\right)$ and $(B)$ testosterone $(T)$ production by mid-vitellogenic follicles during basal and cAMP-stimulated steroidogenesis. The data are shown as mean \% hormone production relative to the relevant control \pm SEM $(n=18)$. Mean basal and cAMP-stimulated E2 production were $0.78 \pm 0.06$ and $1.05 \pm 0.05 \mathrm{pg}$. follicle ${ }^{-1}$, respectively; these differed significantly $(P<0.01)$ from one another. The mean basal and cAMPstimulated T production were $0.46 \pm 0.05$ and $5.29 \pm 1.68$ pg.follicle- 1 , respectively; these differed significantly $(P<0.01)$ from one another. ${ }^{* *}$, *** indicate significant differences $(P<0.01$ and 0.001 , respectively) from the relevant cortisol-treated groups. 
Citation: Barkataki S, Aluru N, Li M, Lin L, Christie H, et al. (2011) Cortisol Inhibition of 17ß-Estradiol Secretion by Rainbow Trout Ovarian Follicles Involves Modulation of Star and P450scc Gene Expression. J Aquac Res Development S2:001. doi:10.4172/2155-9546.S2-001

Page 5 of 8

\begin{tabular}{|c|c|c|}
\hline Concentration of $\mathrm{T}$ in the medium $\left(\mathrm{ng} \cdot \mathrm{ml}^{-1}\right)$ & Control & Cortisol \\
\hline 0 & $0.59 \pm 0.02^{\mathrm{a}}$ & $0.40 \pm 0.03^{\mathrm{a}}$ \\
\hline 10 & $0.77 \pm 0.03^{\mathrm{b}}$ & $0.74 \pm 0.03^{\mathrm{b}}$ \\
\hline 100 & $1.37 \pm 0.03^{\mathrm{c}}$ & $1.37 \pm 0.02^{\mathrm{c}}$ \\
\hline
\end{tabular}

The data are shown as pg.follicle ${ }^{-1}($ mean \pm SEM, $n=6)$. Means within a column with different supercript letters are significantly different from one another; * indicates significant differences $(P<0.05)$ between similar treatments of control and cortisol-treated incubations.

Table 2: Effects of cortisol on the basal synthesis of $17 \beta$-estradiol by ovarian follicles incubated with testosterone $(\mathrm{T})$ present in the medium.

\begin{tabular}{|l|l|l|l|l|}
\hline \multirow{2}{*}{ Gene } & \multicolumn{4}{|c|}{ Treatment groups } \\
\cline { 2 - 5 } & \multicolumn{1}{|c|}{ Basal } & \multicolumn{1}{c|}{ Basal + cortisol } & \multicolumn{1}{c|}{ cAMP } & cAMP + cortisol \\
\hline StAR & $116 \pm 39^{\mathrm{a}}$ & $37 \pm 7^{\mathrm{b}}$ & $403 \pm 99^{\mathrm{c}}$ & $1790 \pm 166^{\mathrm{d}}$ \\
\hline P450scc & $15 \pm 7^{\mathrm{a}}$ & $4 \pm 1^{\mathrm{b}}$ & $30 \pm 7^{\mathrm{a}}$ & $150 \pm 28^{\mathrm{c}}$ \\
\hline
\end{tabular}

The data for each gene were calculated as the copy numbers of specific mRNA relative to the copy numbers of $\beta$-actin mRNA constructs, and shown as mean \pm $\mathrm{SEM}, \mathrm{n}=6$. Means within a row with different superscript letters are significantly different from one another.

Table 3: Effects of cortisol on the relative expression of StAR and P450scc mRNA by ovarian follicles.

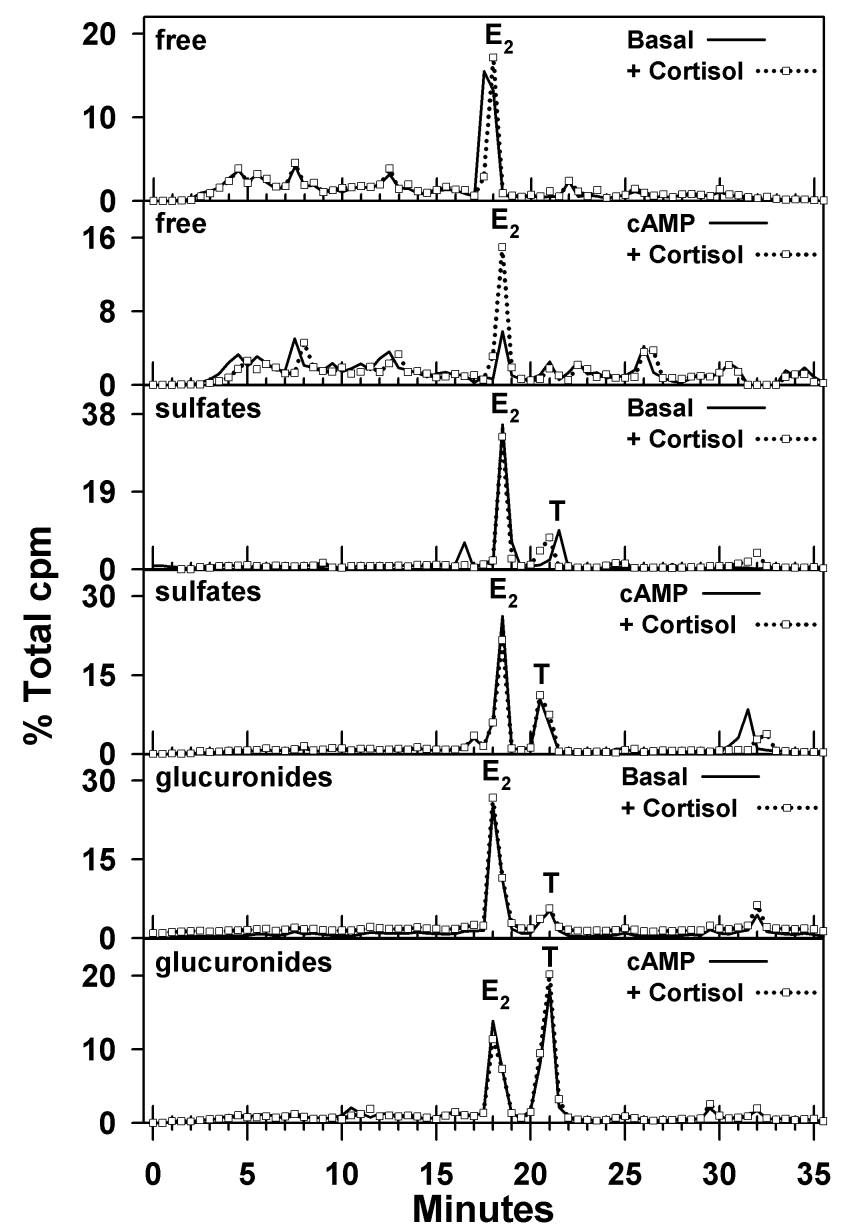

Figure 3: Reverse phase HPLC profiles of unconjugated (free) and conjugated $\left[{ }^{3} \mathrm{H}\right]$-labeled steroids produced from $\left[{ }^{3} \mathrm{H}\right] 17 \mathrm{a}$-hydroxyprogesterone $(17 \mathrm{aOHP})$ by ovarian follicles with and without cortisol in the incubation medium; both basal and CAMP-stimulated steroidogenesis profiles are shown. Abbreviations used in Figures 3, 4 and 5: $\mathrm{A}_{4}$, androstenedione; $\mathrm{E}_{2}$, 17ß-estradiol; PSM, polar steroid metabolites; $\mathrm{T}$, testosterone.
The effect of cortisol on the in vitro metabolism of $\left[1,2,6,7-{ }^{3} \mathrm{H}\right] 17 \mathrm{a}-$ hydroxyprogesterone $\left(\left[{ }^{3} \mathrm{H}\right] 17 \mathrm{\alpha OHP}_{4}\right), \quad[1,2,6,7-3 \mathrm{H}]$ testosterone $\left(\left[{ }^{3} \mathrm{H}\right] \mathrm{T}\right),\left[1 \beta, 2 \beta-{ }^{3} \mathrm{H}\right]$ androstenedione $\left(\left[1 \beta, 2 \beta^{3} \mathrm{H}\right] \mathrm{A}_{4}\right)$ or $[1,2,6,73 \mathrm{H}] \mathrm{A}_{4}$

Two forms of tritiated $\mathrm{A}_{4}$ were used as substrates, namely $[1,2,6,7-$ $3 \mathrm{H}] \mathrm{A}_{4}$ and $\left[1 \beta, 2 \beta-{ }^{3} \mathrm{H}\right] \mathrm{A}_{4}$. The $\left[1 \beta, 2 \beta-{ }^{3} \mathrm{H}\right] \mathrm{A}_{4}$ form was used to look specifically for effects of cortisol on P450arom activity as described by Gore-Langton et al. [35] and Gore-Langton and Dorrington [36], who used the percent of $3 \mathrm{H}$ in the form of ${ }^{3} \mathrm{H}_{2} \mathrm{O}$ in the water eluting from the Sep-Pak columns as a measure of P450arom activity. The [1,2,6,7$\left.{ }^{3} \mathrm{H}\right] \mathrm{A}_{4}$ was used, together with $\left[1 \beta, 2 \beta-{ }^{3} \mathrm{H}\right] \mathrm{A}_{4},\left[{ }^{3} \mathrm{H}\right] 17 \mathrm{OHP}$ and $\left[{ }^{3} \mathrm{H}\right] \mathrm{T}$, to identify the tritiated metabolites, and identify possible sites of cortisol action on different parts of the steroidogenic pathways.

In the present study, the percent of ${ }^{3} \mathrm{H}$ in the form of ${ }^{3} \mathrm{H}_{2} \mathrm{O}$ in the water eluting from the Sep-Pak column after incubation of follicles in the presence of $\left[1 \beta, 2 \beta-{ }^{3} \mathrm{H}\right] \mathrm{A}_{4}$ form were similar in the four treatment groups $(49.9,51.8,51.5$ and $50.2 \%$ for the Basal, Basal + cortisol, cAMP-stimulated and cAMP-stimulated + cortisol treatment groups, respectively), thus indicating that aromatase activities in the four treatment groups sere similar.

The only unconjugated or conjugated steroid products of any

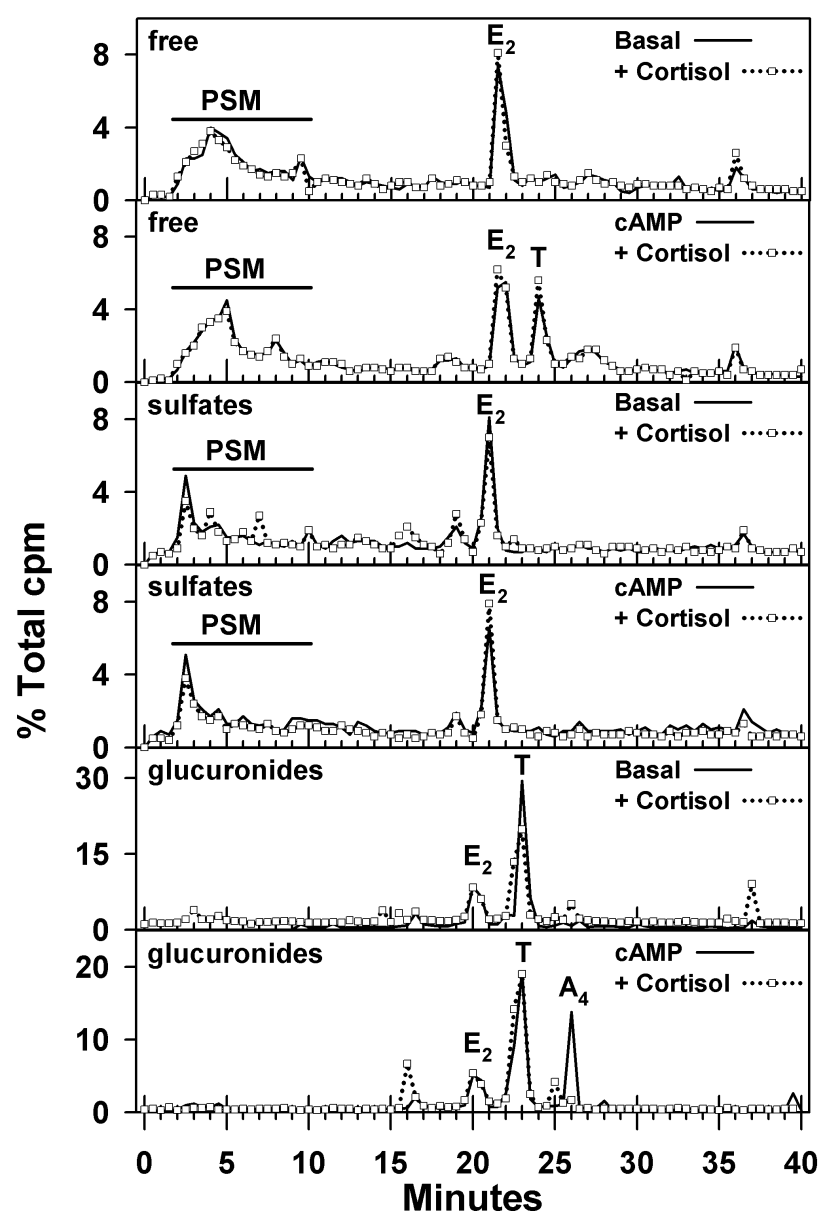

Figure 4: Reverse phase HPLC profiles of unconjugated (free) and conjugated $\left[{ }^{3} \mathrm{H}\right]$-labeled steroids produced from $\left[{ }^{3} \mathrm{H}\right]$-testosterone $\left(\left[{ }^{3} \mathrm{H}\right] \mathrm{T}\right)$ by ovarian follicles with and without cortisol in the incubation medium; both basal and cAMP-stimulated steroidogenesis profiles are shown. Abbreviations: See Legend to Figure 3. 
Citation: Barkataki S, Aluru N, Li M, Lin L, Christie H, et al. (2011) Cortisol Inhibition of 17ß-Estradiol Secretion by Rainbow Trout Ovarian Follicles Involves Modulation of Star and P450scc Gene Expression. J Aquac Res Development S2:001. doi:10.4172/2155-9546.S2-001

consequence following incubation of follicles with $\left[{ }^{3} \mathrm{H}\right] 17 \mathrm{OHP}_{4}$ were $\mathrm{E}_{2}$ in the free fraction and $\mathrm{E}_{2}$ and $\mathrm{T}$ in the sulfate and glucuronide fractions (Figure 3). With the possible exception of the tritium-labeled steroid products in the cAMP-stimulated treatment, in which the $\%$ counts in the $\mathrm{E}_{2}$ fraction in the cortisol treated group were very slightly higher ( $\sim 4$ vs. $\sim 14 \%$ of total counts) than those in the relevant control group, there was no evidence of an effect of cortisol (Figure 3).

Similarly, $\mathrm{E}_{2}$ was a major metabolite in the free and conjugated steroid fractions for the follicles incubated with $\left[{ }^{3} \mathrm{H}\right] \mathrm{T}$ (Figure 4 ) and both forms of $\left[{ }^{3} \mathrm{H}\right] \mathrm{A}_{4}$ (Figure 5), only the $\left[1 \beta, 2 \beta-{ }^{3} \mathrm{H}\right] \mathrm{A}_{4}$ profile is shown. In addition, tritium-labeled polar steroid metabolites ([$\left.\left.{ }^{3} \mathrm{H}\right] \mathrm{PSMs}\right)$ with retention times between 2.0 and 10.0 min were also present in the free steroid fraction following incubation of follicles with $\left[{ }^{3} \mathrm{H}\right]$ androgens (Figures 4 and 5). Smaller amounts of $\left[{ }^{3} \mathrm{H}\right] \mathrm{PSM}$ were also found in the sulfated fractions from follicles incubated with $\left[{ }^{3} \mathrm{H}\right] \mathrm{T}$ (Figure 3). In addition, small amounts of a tritium-labeled steroid sulfate and glucuronide with a retention time similar to $\mathrm{T}$ were also present following the incubation of follicles with tritiated-A (Figure 5).

The presence of cortisol in the incubation medium did not appear to affect the type of steroid products, nor the amounts of steroid products

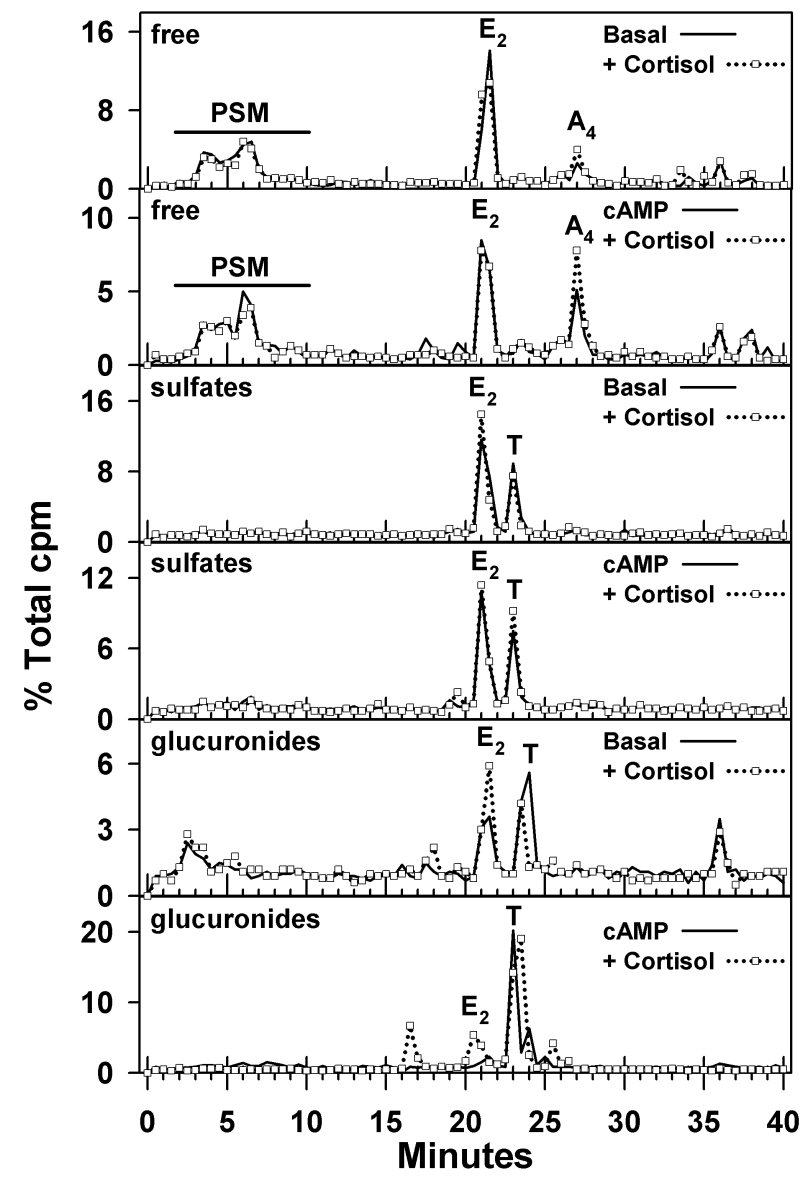

Figure 5: Reverse phase HPLC profiles of unconjugated (free) and conjugated $\left[{ }^{3} \mathrm{H}\right]$-labeled steroids produced from $\left[{ }^{3} \mathrm{H}\right]$ androstenedione $\left(\left[{ }^{3} \mathrm{H}\right] \mathrm{A}_{4}\right)$ by ovarian follicles with and without cortisol in the incubation medium; both basal and cAMP-stimulated steroidogenesis profiles are shown. Similar profiles were found using both $\left([1 \beta, 2 \beta-3 \mathrm{H}] \mathrm{A}_{4}\right.$ and $[1,2,6,7-3 \mathrm{H}] \mathrm{A}_{4}$; only figures based on $\left([1 \beta, 2 \beta-3 H] A_{4}\right.$ metabolism are shown. Abbreviations: See legends to Figure 3. in the unconjugated or conjugated fractions following the metabolism of $\left[{ }^{3} \mathrm{H}\right] \mathrm{T}$ or $\left[{ }^{3} \mathrm{H}\right] \mathrm{A}_{4}$ (Figures 4 and 5).

\section{Discussion}

The present study uses isolated fish ovarian follicles incubated in vitro to identify possible sites of direct action of cortisol on ovarian steroidogenesis; these in vitro studies eliminated many of the factors, such as actions on the HPO axis, that may be involved in the responses to cortisol in vivo. Based on the present and earlier studies of ovarian follicle steroidogenesis in rainbow trout, several separate pieces of evidence suggest that at least one of the inhibitory actions of cortisol on $\mathrm{E}_{2}$ synthesis occurs in the steroidogenic pathway prior to the formation of androgens and likely at an early stage in the synthesis of progestogens. First, both $\mathrm{E}_{2}$ and $\mathrm{T}$ synthesis were inhibited in the presence of cortisol (Figure 1B), suggesting that the inhibition occurred before the progestogen-to-androgen biotransformation by the thecal cells (Figure 1). Second, when T was added to the incubation medium there was a dose-dependent increase in synthesis of $\mathrm{E}_{2}$, which was not suppressed in the presence of cortisol in the medium (Table 2); this suggests that cortisol does not suppress the biotransformation of androgens to estrogens by the granulosal cells. Third, previous studies showed that mid-vitellogenic stage ovarian follicles incubated in the presence of $\left[{ }^{3} \mathrm{H}\right] \mathrm{P}_{5}$ showed a marked reduction in the formation of $\left[{ }^{3} \mathrm{H}\right] \mathrm{E}_{2}$ when cortisol was in the medium $[23,26]$, but there was no indication of a suppressive action of cortisol on $\mathrm{E}_{2}$ (or $\mathrm{T}$ ) synthesis when follicles were incubated in the presence of $\left[{ }^{3} \mathrm{H}\right] 17 \mathrm{\alpha OHP}{ }_{4}$ (Figure 3). This also supports the hypothesis that the suppressive action of cortisol on steroidogenesis occurs very early in steroidogenesis. Fourth, in the present study, with $\left[{ }^{3} \mathrm{H}\right] \mathrm{T}$ or $\left[{ }^{3} \mathrm{H}\right] \mathrm{A}$ as the substrate (Figures 4 and 5) there was no evidence of a cortisol-related suppression of $\left[{ }^{3} \mathrm{H}\right]$ $\mathrm{E}_{2}$ accumulation in the free or conjugated fractions; this also supports the argument that cortisol does not compromise P450arom function, as does the finding of no treatment affects on the formation of ${ }^{3} \mathrm{H}_{2} \mathrm{O}$ from $\left[1 \beta, 2 \beta-{ }^{3} \mathrm{H}\right] \mathrm{A}_{4}$. Interestingly, this apparent absence of an action of cortisol on ovarian aromatase activity may not be the case for all fish species at all developmental stages. Two recent studies, one in the Japanese flounder (Paralichthys olivaceous) [37] and one in medaka (Oryzias latipes) [38] both provided evidence of cortisol promoting masculinization of genetically female fish, in part by acting to inhibit P450arom activity or the expression of P450arom genes.

A candidate site for the action of cortisol is at the level of the steroidogenesis rate-limiting StAR protein transport of cholesterol into the mitochondria of thecal cells. This is suggested by the significant reduction in the abundance of StAR mRNA transcripts in the ovarian follicles undergoing basal steroidogenesis incubated in the presence of cortisol (Table 3). Cortisol actions on the P450scc enzyme may also play a part since there was also a significant reduction in P450scc mRNA abundance. Of considerable interest was the finding that this was not seen for CAMP-stimulated steroidogenesis, where the relative expression of StAR and P450scc genes by follicles incubated with cortisol was significantly $(\mathrm{P}<0.01)$ elevated compared with all other treatment groups. This suggests an anticipated up-regulation of these genes in response to cAMP stimulation, but the higher accumulation of mRNA in response to cortisol stimulation is indicative of a cortisol-modulating affect at a different level. This response of higher mRNA abundance in the mid-vitellogenic stage follicles was not reflected in an increased $\mathrm{E}_{2}$ production, nor in an increased processing of $\left[{ }^{3} \mathrm{H}\right]$-labeled substrates, which suggests that although mRNA levels were enhanced by cortisol, there was no concomitant translation of the mRNA constructs to form proteins, or that there was no post-translational activation of protein 
Citation: Barkataki S, Aluru N, Li M, Lin L, Christie H, et al. (2011) Cortisol Inhibition of 17ß-Estradiol Secretion by Rainbow Trout Ovarian Follicles Involves Modulation of Star and P450scc Gene Expression. J Aquac Res Development S2:001. doi:10.4172/2155-9546.S2-001

products. It is also possible that mRNA accumulates abnormally because of the continuous cAMP stimulation by Forskolin, and this might limit the ability of the steroidogenic cells to degrade the accumulated mRNA constructs. Yet another explanation might be that there is insufficient cholesterol substrate available to allow the production of P5, or that the $18 \mathrm{~h}$ incubation period was not sufficient to allow protein synthesis to occur.

The incubations of ovarian follicles with $\left[{ }^{3} \mathrm{H}\right] \mathrm{T}$ or $\left[{ }^{3} \mathrm{H}\right] \mathrm{A}_{4}$ resulted in the formation of $\left[{ }^{3} \mathrm{H}\right]$ polar steroid metabolites (PSMs), the presence of which suggests that $\mathrm{E}_{2}$ may not be the end-product of steroidogenesis. Although a peak that co-eluted with authentic $\mathrm{E}_{2}$ was a major product, steroid metabolites eluting from the column between approximately 2.0 and 10.0 min were consistently present as a major metabolite component in the unconjugated steroid fractions, but to a much lesser extent in the steroid sulfate or glucuronide fractions. Based on the retention time range of these PSMs, it is possible that they may be metabolites of $\mathrm{E}_{2}$, such as 6-hydroxyestrogens which have retention times on the same reverse phase HPLC system used for the present study of between 2.0 and $12.0 \mathrm{~min}$ (data not shown). Neutral/phenolic separation of the PSM fractions suggests, that both estrogen and androgens may be present (data not shown). These metabolites did not cross-react with the $\mathrm{E}_{2}$ antibody used for the RIA, and thus they did not contribute to the measured values of $\mathrm{E}_{2}$ in the medium; moreover, there was no evidence of cortisol affecting the level of production of these steroids. Thus, the reduced $\mathrm{E}_{2}$ synthesis based on the RIA data is more likely the result of decreased steroidogenesis, rather than increased metabolism of $\mathrm{E}_{2}$. Further work is needed to determine the nature of these steroid products that were derived from $\mathrm{T}$ or $\mathrm{A}_{4}$ substrates.

In summary, the present studies indicated that the suppressive action of cortisol on $\mathrm{E}_{2}$ synthesis appears to be associated, at least in part, with a reduction in StAR or P450scc mRNA abundances or, in the case of cAMP-stimulated situations, altered mRNA stability.

\section{Acknowledgements}

We wish to thank the Alma Aquaculture Station staff for their excellent assistance and Dr. James Raeside (Biomedical Sciences, Guelph) for his advice and guidance regarding the identification of some of the steroid metabolites. The study was supported by National Science and Engineering Research Council Discovery grants (JFL, MMV), an Ontario Ministry of Agriculture and Food research grant (JFL), an NSERC Postdoctoral Fellowship (NA) and a Graduate Student Scholarship (ML).

\section{References}

1. Leatherland JF, Li M, Barkataki S (2010) Stressors, glucocorticoids and ovarian function in teleosts. J Fish Biol 76: 86-111.

2. Schreck CB (2010) Stress and fish reproduction: The roles of allostasis and hormesis. Gen Comp Endocrinol 165: 549-556.

3. Chand D, Lovejoy DA (2011) Stress and reproduction: Controversies and challenges. Gen Comp Endocrinol 171: 253-257.

4. Leatherland JF, Ferris J, Li M (2011) Comparison of the affect of stress on ovarian function, reproduction and neonatal outcomes in fish and mammals: An exploration into the possible mechanisms of action. In: Wendelaar Bonga SE Peter S, Peter, B (eds). The Physiology of Stress, Springer. (In press).

5. Andersen CY (2002) Possible new mechanism of cortisol action in female reproductive organs: Physiological implications of the free hormone hypothesis. J Endocrinol 173: 211-217.

6. Michael AE (2003) Life after liquorice: The link between cortisol and conception. Reprod Biomed Online 7: 683-690.

7. Thurston LM, Norgate DP, Jonas KC, Chandras C, Kloosterboer HJ. et al (2002) Ovarian modulators of $11 \beta$-hydroxysteroid dehydrogenase (11ßHSD) activity in follicular fluid from gonadotropin-stimulated assisted conception cycles. Reproduction 124: 801-812.
8. Thurston LM, Norgate DP, Jonas KC, Gregory L, Wood PJ, et al. (2003) Ovarian modulators of type $111 \beta$-hydroxysteroid dehydrogenase (11ßHSD) activity in intra-follicular cortisol:cortisone ratios correlate with the clinical outcome of IVF. Hum Reprod 18: 1603-1612.

9. Tomlinson JW, Walker EA, Bujalska IJ, Draper N, Lavery GG, et al. (2004) $11 \beta$-Hydroxysteroid dehydrogenase type 1: A tissue-specific regulator of glucocorticoid response. Endocr Rev 2: 831-866

10. Draper N, Stewart PM (2005) 11 $\beta$-Hydroxysteroid dehydrogenase and the prereceptor regulation of corticosteroid hormone action. J Endocrinol 186: 251 271.

11. Michael AE, Papageorghiou AT (2008) Potential significance of physiologica and pharmacological glucocorticoids in early pregnancy. Hum Reprod Update 14: 497-517.

12. Webb RJ, Sunak N, Wren L, Michael AE (2008) Inactivation of glucocorticoids by $11 \beta$-hydroxysteroid dehydrogenase enzymes increases during the meiotic maturation of porcine oocytes. Reproduction 136: 725-732.

13. Yang JG, Chen WY, Li PS (1999) Effects of glucocorticoids on maturation of pig oocytes and their subsequent fertilizing capacity in vitro. Biol Reprod 60 929-936.

14. Andersen CY (2003) Effect of glucocorticoids on spontaneous and folliclestimulating hormone induced oocyte maturation in mouse oocytes during culture. J Steroid Biochem Mol Biol 85: 423-427.

15. Nepomnaschy PA, Welch K, McConnell DS, Strassman BI, England BG (2004) Stress and female reproductive function: A study of daily variations in cortisol gonadotrophins, and gonadal steroids in a rural Mayan population. Am J Hum Biol 16: 523-532.

16. Arck P, Hansen PJ, Jericevic BM, Piccinni MP, Szekeres-Bartho J (2007) Progesterone during pregnancy: Endocrine-immune cross talk in mammalian species and the role of stress. Am J Reprod Immunol 58: 268-279.

17. Wagenmaker ER, Breen KM, Oakley AM, Pierce BN, Tilbrook AJ, et al. (2009) Cortisol interferes with the estradiol-induced surge of luteinizing hormone in the ewe. Biol Reprod 80: 458-463.

18. Schreck CB, Contreras-Sanchez W, Fitzpatrick MS (2001) Effects of stress on fish reproduction, gamete quality, and progeny. Aquaculture 197: 3-24

19. Milla S, Wang N, Mandiki SNM, Kestemont P (2009) Corticosteroids: Friends or foes of teleost fish reproduction. Comp Biochem Physiol A Mol Integr Physiol. 153: $242-251$.

20. Vijayan MM, Aluru N, Leatherland JF (2010) Stress response and the role of cortisol. In: Leatherland JF, Woo PTK (eds.). Fish Diseases and Disorders, Vol 2, Non-Infectious Disorders $2^{\text {nd }}$ Edition. CABI Publishing, New York, pp.182 201

21. McEwen BS, Wingfield JC (2003) The concept of allostasis in biology and biomedicine. Horm Behav 43: 2-15

22. Milla S, Jalabert B, Rime H, Prunet $P$, Bobe J (2006) Hydration of rainbow trou oocyte during meiotic maturation and in vitro regulation by $17,20 \beta$-dihydroxy-4pregnen-3-one and cortisol. J Exp Biol 209: 1147-1156.

23. Barkataki S (2008) In vitro Stressor-Related Changes in Ovarian Steroidogenesis in Rainbow Trout (Onchorhynchus mykiss). MSc Dissertation University of Guelph, ON, Canada. 145p.

24. Li M (2011) The Actions of Cortisol on Rainbow Trout (Oncorhynchus mykiss) Early Embryo Developmental Biology. PhD Thesis Dissertation, University of Guelph, ON, Canada. 289p.

25. Li M, Bureau D, King WA, Leatherland JF (2010) The actions of cortisol in ovo on egg fertility, embryo development and growth performance of juvenile rainbow trout. Mol Reprod Dev; 77: 922-31.

26. Jones PM, Sayed SB, Persaud SJ, Burns CJ, Gyles S, et al. (2000) Cyclic AMP-induced expression of steroid acute regulatory protein is dependent on phosphoprotein phosphatase activities. J Mol Endocrinol 24: 233-239.

27. Kusakabe M, Todo T, McQuillan HJ, Goetz FW, Young G (2002) Characterization and expression of steroidogenic acute regulatory protein and MLN64 cDNAs in trout. Endocrinology 143:2062-2070.

28. Li YY, Inoue K, Takei Y (2003) Steroidogenic acute regulatory protein in eels: cDNA cloning and effects of ACTH and seawater transfer on its mRNA expression. Zoolog Sci 20: 211-219.

29. Hagen IJ, Kusakabe M, Young G (2006) Effects of ACTH and cAMP on 
Citation: Barkataki S, Aluru N, Li M, Lin L, Christie H, et al. (2011) Cortisol Inhibition of 17ß-Estradiol Secretion by Rainbow Trout Ovarian Follicles Involves Modulation of Star and P450scc Gene Expression. J Aquac Res Development S2:001. doi:10.4172/2155-9546.S2-001

steroidogenic acute regulatory protein and P450 11ß-hydroxylase messenger RNAs in rainbow trout interrenal cells: Relationship with in vitro cortisol production. Gen Comp Endocrinol 145: 254-262.

30. Miller WL (2007) Mechanism of StAR's regulation of mitochondrial cholestero import. Mol Cell Endocrinol 265/266: 46-50.

31. Khan MN, Reddy PK, Renaud RL, Leatherland JF (1997) Effect of cortisol on the metabolism of $17 \alpha$-hydroxyprogesterone by Arctic charr and rainbow trout embryos. Fish Physiol Biochem 16: 197-209.

32. Leatherland JF, Ogasawara K, Rahman MS, Renaud R, Yamashiro H et al. (2003) in vitro steroidogenesis of the gonads of the protogynous Pacific wrasse, Haliochoeres trimaculatus. J Fish Biol 62: 1414-1434.

33. Petkam R, Renaud R, Lin L, Boermans H, Leatherland JF (2005) Effect of sub-lethal levels of dichlorodiphenyltrichloroethane and dichlorodiphenyldichloroethylene on in vitro biosynthesis by ovarian follicles or steroid metabolism by embryos of rainbow trout (Onchorynchus mykiss). Aquat Toxicol 73: $288-298$
34. Raine JC, Cameron C, Vijayan MM, LaMarre J, Leatherland JF (2004) The effect of elevated oocytes triiodothyronine content on development of rainbow trout embryos and the expression of mRNA encoding for thyroid hormone receptors. J Fish Biol 65: 206-226.

35. Gore-Langton R, McKeracher H, Dorrington J (1980) An alternative method fo the study of follicle-stimulating hormone effects on aromatase activity in Sertoli cell cultures. Endocrinology 107: 464-471.

36. Gore-Langton RE, Dorrington JH (1981) FSH induction of aromatase in cultured rat granulose cells measured by a radiometric assay. Mol Cell Endocrinol 22 135-151.

37. Yamaguchi T, Yoshinaga N, Yazawa T, Gen K, Kitano T (2010) Cortisol is involved in temperature-dependent sex determination in the Japanese flounder Endocrinology 151: 3900-3908.

38. Hayashi Y, Kobira H, Yamaguchi T, Shiraishi E, Yazawa T, et al. (2010) High temperature causes masculinisation of genetically female medaka by elevation of cortisol. Mol Reprod Dev 77: 679-686.
This article was originally published in a special issue, Current and Emerging Diseases/Disorders of Fish in Aquaculture handled by Editor(s). Prof. Patrick T.K. Woo, University of Guelph, Canada; Dr. Kenneth D. Cain, University of Idaho, USA. 